\title{
The polygynous household in Lola Shoneyin's The Secret Lives of Baba Segi's Wives: a haven in a heartless world
}

\author{
F. Fiona Moolla
}

\begin{abstract}
:
Despite Lola Shoneyin's public condemnation of the impediments to female autonomy, equality, freedom, dignity, and self-realisation inherent in polygamy, the polyvalent nature of her contemporary Nigerian novel, The Secret Lives of Baba Segis Wives, suggests the necessary material and moral complexity of any analysis of plural marriage in postcolonial Africa. Parodic play in this novel highlights how the apparently monstrous patriarch and the daily perversions of traditional marriage and household ideals represent the only security for both relatively advantaged and disadvantaged women in twenty-first-century Nigeria. I embed my literary analysis of the novel within a survey of history and religion to show how monogamy confirmed the moral superiority of the colonial and Christian missionary projects and justified their social interventions. To contextualise this study of the novel, I also use socio-anthropological literature that connects the global forces promoting romantic love as the sole foundation of monogamous marriage with, ironically, the global flows that create the punitive economic and social conditions to which plural marriage is an entirely rational response shaped by local cultural contexts.
\end{abstract}

Lola Shoneyin's reputation in Nigeria, where she was already established as a poet, has grown nationally and internationally with the success of her first novel, The Secret Lives of Baba Segis Wives (2010). Her background in poetry is evident in the novel's compression and finely balanced architecture of expression, penchant for striking images, and lyricism. The title of the novel clearly states that the main subject of the novel is the controversial and culturally contentious question of polygamy. While the novel censures polygamy, it also criticises distorted versions of the dominant ideal of monogamy. Despite the dual critique, most reviews of the novel and the drift of author interviews claim that the thrust of the novel is directed mainly at exposing the toxicity of polygamy in the modern world.

While the novel casts a glance at both polygamous and monogamous households, it presents in its preliminary pages a family tree only of the polygamous household that is its primary emphasis. The novel also reflects its subject matter at the level of narrative structure. The plural nature of the marriage of the Yoruba patriarch, Ishola Alao, is replicated in the manifold voices presented in the story. The novel's short chapters combine first-person narration of the many household members and third-person narration focalised through the same characters. Both first- and third-person narratives offer flashbacks, which allow the reader to construct short biographies for each of the significant characters. Despite its narrative attempt to present the 
eminently social world of the polygamous household, the book defaults to the tendency of the novelistic genre to foreground the individual life. The character that emerges most clearly through both the constitution of her rich inner life and her personal development in the novel is Bolanle, who is caustically referred to by the non-literate wives as "the graduate." Bolanle is the fourth and final wife to enter the Alao household and acts as a catalyst to finally fully expose the family's marital secret and the oppressiveness of polygamy.

Another striking feature of the novel is its humour. Shoneyin creates humour through scenes of bawdy, naturalistic, slapstick comedy generated from the earthy expressions and actions of the characters the novel classes as traditional. She also creates humour through satire, irony, and parody of the social trends and characters that the novel classes as modern. The novel cynically critiques modern popular romance and exposes distorted postcolonial versions of materialistic modern monogamy as well as the violence and hypocrisy of misogynistic, hedonistic contemporary relationships based on individual freedom and pleasure. The only character to escape lampooning is the heroine, Bolanle. In her self-realisation, she represents the possibility of an ideal monogamy, though its nature is not spelled out in this fairly open-ended novel. While the novel variously constructs, at a surface level, the familiar tradition/modernity dichotomy, a squint-eyed view of the narrative dynamics suggests the paradoxes and contradictions of this idea, as this essay will show through an analysis of the related polygamy/monogamy binary.

Thus, although the novel parodies a broad range of traditional and modern institutions, only polygamy is presented as irredeemable through the character of Bolanle and the recouping of the moral and civilisational superiority of monogamy. The novel's central ideological position, which emerges most clearly at the end of the novel, is at odds with contemporary trends in marriage identified by sociologists and certainly contradicts the economic and relationship dynamics at the heart of the novel, which reveal urban polygamy in the twenty-first-century postcolony as providing wives with the social possibility for emotional and financial security and, yes, even a limited freedom, despite its tensions and complications. My consideration of Secret Lives follows a brief social, cultural, religious, and political history of polygamy that provides a context for analysis. This essay will also map a literary history through an overview of representations of polygamy in African literature.

\section{A Potted History of Polygamy: Religion, Anthro-Sociology, History}

Polygamy is a part of the origin myths and historical development of most major religions and many world cultures. In Sexual Morality in the World's Religions, Geoffrey Parrinder identifies various forms of polygamy in the major religions, including Buddhism, Hinduism, Confucianism, the Sikh and Parsi creeds, African traditional religions, and the three Abrahamic faiths. Citing the findings of David P. Barash and Judith Eve Lipton in Strange Bedfellows: The Surprising Connection between Sex, Evolution and Monogamy and George P. Murdock's Ethnographic Atlas, Judith Stacey, the author of Unhitched: Love, Marriage and Family Values from West Hollywood to Western China suggests, in addition, that "more than three-quarters of all human societies were polygynous. Monogamy was the preferred norm in fewer than one-quarter of human societies" (124). Since the twentieth century, however, plural marriage has come to be identified mainly 
with an ossified idea of African tradition and Islamic law. The shift away from formalised polygamy in most world cultures may be linked with the effects of colonial norms of family life reinforced by Victorian cultural evolutionary hierarchies. Referring to the African experience, Miriam Koktvedgaard Zeitsen highlights that colonists regarded Africans, in particular, to be sub-human and that part of their humanising and civilising mission involved introducing European ways of life. For Africans, "giving up polygamy" was one of the "important elements" of adjusting to European civilization (Zeitsen 145). Polygamy was considered a "social evil" linked with the "economic serfdom" of women and children, which "hinder[ed] the economic and intellectual advancement of the country" (145). These attitudes were supported by missionary Christianity, which Zeitsen characterises as launching a "crusade" against polygamy by foregrounding the salvation of women: "It is only by the law of the Gospel, incorporated in social life, that the Black woman will be delivered from the shame and slavery of polygamy and attain to the liberty of the children of God and to the high dignity of the Christian wife and mother" (Van Wing qtd. in Zeitsen 147). Gayatri Chakravorty Spivak's well-known essay "Can the Subaltern Speak?" reveals the gendered moral justification for Indian colonialism presented by the British outlawing of sati-suicide. Putting a different spin on Spivak's idea in the African colonial context, the eradication of polygamy formed the central thrust of white men saving black women from black men.

Normative heterosexual monogamy in the European tradition may be linked with the rise of companionate marriage in the seventeenth century, where romantic love between two people conceived as individuals became the primary foundation for marriage. The rise of companionate marriage has been tracked by a number of scholarly works but principally in Lawrence Stone's monumental book, The Family, Sex and Marriage in England 1500-180o. Monogamy, which structurally embodies the concept of companionate marriage, is reinforced in the colonial cultural imaginary as a defensive response to the "backwardness" of the polygamy it encounters in the colonies. Underlining this paradox, Zeitsen observes that historically, various Christian denominations (Lutheranism included) have tacitly accepted polygamy and that the contemporary stance that opposes plural marriage is, in part, a consequence of politically fraught colonial encounters with other religions. As Zeitsen states,

[t]oday, the Christian Church clearly condemns polygamy, not least as a result of the last 200 years of colonial history, where the intercultural confrontation between colonizer and colonized often took the form of religious confrontation. Faced with polygamous, animistic peoples, European administrators and missionaries made polygamy one of the main issues with which to force their way of life upon their new subjects. (34)

As globalisation has superseded colonialism, the geographically and historically localised conception of intimate relations and partnerships, crystallised in companionate marriage, has risen to dominance and is now imagined in most of the world as universal and natural, particularly because urbanisation (and in a parallel sense, modernisation) has forced a reconfiguration of diverse forms of family structure. (Paradoxically, the individualising assumptions of the dyadic love marriage as a form of personal fulfillment that undergird the heterosexual companionate marriage also provide the rationale for homosexual companionate 
marriage in the late twentieth and twenty-first centuries. If the purpose of marriage consists mainly in personal self-realisation and happiness delinked from questions of social survival, then marriage may be contracted by consenting adults, regardless of gender.) In Jennifer Cole and Lynn Thomas' Love in Africa, a number of contributors draw attention to contemporary reconfigurations of intimate relations and marriage, especially among the African middle classes, as a result of urbanisation, higher levels of formal education, and the influence of local and global popular culture, which promotes the ideal of voluntary monogamous love matches. In most world cultures, the incipient shift to heterosexual monogamy can be traced back to the nineteenth century, with polygamy becoming legally outlawed in the twentieth century. In an Asian context, Malavika Karlekar's study of Kulin polygyny (in which a man has multiple wives) is a case in point. Kulins, as the highest-ranking Brahmins of Bengal, often took numerous wives-up to one hundred-until the practice was prohibited by legislation in 1956 .

Colonial and missionary ideologies, human rights discourses, and North-Atlantic feminism have identified polygyny as inherently barbaric and oppressive toward women.

Yet studies have shown that polyandry (in which a woman has multiple husbands) and matrilineality do not necessarily translate into higher female status. Furthermore, one aspect of feminist struggles in monogamous societies suggests the inscription of gender imbalances even in the modern heterosexual companionate marriage that was presented as confirming respect and equality for the monogamous wife, most strikingly underscored in colonial and missionary discourses.

There are three exceptions to the general legal injunction against polygyny and the presentation of monogamy as a universal ideal in dominant global culture in the twentieth and twenty-first centuries. The first challenge to the proscriptive pattern occurs in African cultures, where the power of cultural pro-life attitudes acts as a dynamo for the perpetuation of polygamous relations. David Maillu suggests that childbirth is the primary purpose of marriage in Africa: "The first natural acceptance to the African, in so far as woman-to-man sexual relation in marriage is concerned, is that their coming together is primarily to procreate" (3). The response to infertility in African cultures has been collectively creative and practical. Polygyny resolves the problem of female infertility, and a tacit polyandry, where a male relative impregnates the wife, resolves the problem of male sterility. The second variation on the trend is observed in predominantly Islamic countries where religious law unambiguously permits polygyny limited to four wives, but the practice is regulated by conditions regarding equality of spouses and adequate material means to support an extended family. The third is Mormon fundamentalism. The three cases above epistemologically represent other local and translocal challenges to the dominance of monogamy in the global cultural imaginary.

The broader social outlooks that preserve polygyny in the twentieth and twenty-first centuries in African traditional religions and Islam are, paradoxically, reinforced by modernity. Even in parts of the Muslim world and among African families where monogamy has prevailed, polygyny has become a marker of prestige in the formation of elites in modern nation states. Augustine Nwoye draws a distinction in an African context between interventive polygamy, 
which occurs in the context of and as an attempt to alleviate family stress, such as in the case of infertility discussed above, and affluent polygamy, which is a marker of social prestige and economic ambition. Affluent polygamy becomes more widespread as a reinvention and manipulation of "tradition" in the context of modern identity politics. For example, South African president Jacob Zuma's plural marriage symbolises both his status as a "big man" and acts as a contemporary assertion of Zulu identity. While polygyny has always existed in Zulu culture, and has always acted as a marker of social status, it was an integrated feature of a coherent and flexible apprehension of social order. Polygyny, among other reinvented traditions, is postcolonially appropriated as a marker of Africanness in the wholly transformed order of the modern African nation state to distinguish its culture from the culture of the European nation-state models from which it is derived. Polygyny, in the context of the modern nation state, furthermore, along with other cultural symbols, is a deliberate assertion of Zuluness in an ethnically and religiously plural state where, nevertheless, ethnicity creates allegiances that may be politically mobilised.

The general popular and scholarly consensus, in addition, is that indigenous African polygyny is reinforced in parts of Africa that have been Islamised. But, of course, polygyny is not exclusively an African and Islamic phenomenon. Depending on how the idea of marriage is conceptualised, polygyny exists in other cultures as concubinage, long-term extra-marital affairs, serial monogamy, and other forms of de facto polygyny.

\section{One Man, Many Wives: African Literary Representations of Polygyny}

What then could be more apt a subject for African writing in general and the African woman writer in particular than polygyny, which has been globally defined as a specifically African "problem"? Astonishingly, however, coming up with examples of African literature that make polygyny their major focus is hard. In fact, a survey of dictionaries and encyclopaedias of African literature is revealing: in the range of reference works I consulted, including the various Columbia guides and Simon Gikandi's Encyclopaedia of African Literature, polygamy or polygyny are not represented by full entries, and the few page references to polygamy or polygyny that exist in other entries are very general. These literary reference works suggest that in African male writing, a defence of polygyny emerges in the late nineteenth and first quarter of the twentieth century as a counter-discourse in non-fiction tracts to colonial marriage ordinances and missionary condemnations of the practice as anti-Christian. Considering works which have been canonised as part of the trajectory of African literature, rather than the non-fiction works discussed above, polygyny is generally addressed from a number of points of view in the works of a few male fiction writers. It forms the specific focus of the 1959 novel by T. M. Aluko, One Man, One Wife, and the 1970 novel, The Victims, by scholar of orature and fiction writer Isidore Okpewho. It is also addressed in a 1972 novel by the Zimbabwean author Ndabaningi Sithole called The Polygamist. While Aluko's novel shows a polygyny so culturally entrenched that even Christianised Africans cannot abide by the monogamous ideal of the Christianity they have adopted, Okpewho and Sithole highlight the problems of polygyny in transformed material circumstances. In this respect, both Sithole's and Okpewho's novels predate the concerns of the work of women writers like Mariama Bâ, Buchi Emecheta, and Ama Ata Aidoo. Both these male 
and female writers highlight the anomalies and injustices of modern forms of urban polygyny that prevail when the norms and mores of the countryside are transposed onto the colonial city.

In the works of most African women writers, polygyny exists mainly as part of a general background against which other issues are explored. Emecheta's The Joys of Motherhood is a case in point. The focus of the novel falls squarely on the Igbo procreation imperative, which drives the protagonist Nnu Ego's life, while various culturally endorsed rationales for the husband's multiple marriages form the backdrop. But there are few examples in which polygyny is a central exploration in works of fiction by women writers. Polygyny provides the specific narrative impetus of a 1947 short story by Nigerian writer Mabel Dove Danquah titled "Anticipation," and Senegalese writer Mariama Bâ's 1981 novel, So Long a Letter, has achieved iconic status as the African novel that addresses and critiques polygyny head on. But even in Bầs novel Obioma Nnaemeka observes a disjunction between the books themes and criticism. Reading So Long a Letter in the original French, Nnaemeka points out that "[i]t is puzzling that a book, Une si longue lettre/So Long a Letter, in which the word 'la polygamie/polygamy never appears and polygamy (the institution) never functions . . . has been debated and analyzed ad nauseam in literary criticism (feminist criticism, in particular) as a book about the institution of polygamy (derided as one of Africa's chronic ailments)" (164; emphasis in original). According to Nnaemeka, Bâ explores the "polygamous instincts" of men in the context of "cultural hemorrhage and societal rearticulations" attendant upon colonial transformations of African countries and cultures (164).

Aidoo is the next African woman writer who turns her gaze directly onto polygyny in her 1993 novel, Changes: A Love Story. In this story, polygyny is not forced upon the protagonist by a husband who manipulates tradition to his advantage; rather, it is the lifestyle option of choice for a fully autonomous, financially independent Ghanaian woman who nevertheless is left unfulfilled in the urban plural marriage. The novel thus contradicts the assumption that only backward, uneducated women enter polygynous families as victims of tradition, since in this case, polygyny grants Esi, the protagonist, the autonomy and freedom from domestic responsibility that she requires for personal self-fulfillment. (We see a variation of this scenario in Secret Lives in which a formally educated woman chooses polygyny but for traumatic personal reasons.)

It might be argued that African women writers have, with the exception of the few cases above, largely strategically avoided tackling the question of polygyny directly since it is a topic that is simply too controversial. While criticism of polygyny may be construed as a rejection of African tradition in favour of colonial modernity, promoting polygyny may be viewed as undermining the gains of anti-patriarchal struggles in the context of a "universal" feminist individualism. I contend that African women writers have not been shy of controversy. Despite Bâs's complex and nuanced treatment of the topic in So Long a Letter, many African male critics read the novel as an unthinking acceptance of culturally specific Western feminism. Emecheta explicitly presents polygyny as a central strength of African feminism in "Feminism with a small 'f'!" and she does not avoid the arguably "touchier" subject of African mothering in The Joys of Motherhood. If African women writers have neglected to explore polygyny in their fiction it is not out of fear of being considered cultural sell-outs. More likely, the practice has been viewed as unoppressive where it has not been adulterated by fundamental social, cultural, and economic shifts. 
Shoneyin's Secret Lives is the most recent novel with international circulation that addresses the question of polygyny. The novel, along with the large number of fictional works in local languages and the popular "market" literatures in English that are not surveyed in this essay, highlights the fact that plural marriage in Africa is an enduring social phenomenon into the twenty-first century, despite the cultural dominance of monogamy in colonial and then global culture. In the latter range of popular works, polygyny does not occur as a problem to be overcome; it is instead one in a range of personal relationships that forms an unexceptional backdrop to social equilibrium.

Thus the institution of polygyny that has come to define the patriarchal victimhood of African women by African/Islamic tradition has been directly addressed in only three novels and one short story by African women writers and is only indirectly considered in a number of others, most notably The Joys of Motherhood. Clearly, for most African women writers polygyny has not been the major social challenge to be creatively explored. It is one of a range of practices, the transformation of which in the colonial world seemed to impact differentially (and sometimes unfairly) on women. This is a point Nnaemeka makes strongly in her analysis of So Long a Letter. The polygyny of the precolonial African village, in which each wife had her own space and role in the family and community structures, is destabilised when transferred to the colonial city. Often modern urban polygyny is a form of monogamised polygamy that formalises the husband's adultery in ways that are socially unjust for the women concerned. Shoneyin's Secret Lives asks readers to reappraise polygyny as it becomes, in a globalised twenty-first-century urban Nigeria, a refuge for women when the promises of progress and advancement of postcolonial modern nationhood, for complex reasons, are broken. But even as the novel shows that polygynous marriage, in some contexts, represents the only security for women, it finally endorses the globally dominant ideal of monogamy.

\section{Unruly Polygyny in The Secret Lives of Baba Segi's Wives}

What is most fascinating about Secret Lives is its boisterous and disruptive counter-life, like a wayward child who defies the dictates of Shoneyin, its author-parent. In author interviews, Shoneyin claims quite categorically that polygyny is morally offensive and ought to be eradicated. She declares that "[h]usband-sharing is ugly" in a Guardian author profile titled "Polygamy? No Thanks." She explains her position by narrating her family history, in which a hereditary chieftainship obliged the "modern marriage" of her grandparents to take a step backward into polygyny with her grandfather marrying four other women. The experience made Shoneyin's own mother wary of plural marriage, against which she warned her daughter: "[Polygynous wives] might be smiling on the outside, but inside they [are] sad and bitter." Shoneyin's parents, for whom the ethnicity of their children's partners is not an issue, also cautioned her brothers against dating girls from polygynous homes since they have to be "devious" to survive. In the context of public, apparently politically motivated Nigerian plural marriages, Shoneyin concludes the article by suggesting that "[t]he sad truth is, polygamy constitutes a national embarrassment in any country that fantasises about progress and development. Polygamy devalues women and the only person who revels in it is the husband who gets to enjoy variety. You, poor women, will become nothing more than a dish at the buffet." 
Although the author reflects almost point for point the Christian missionaries' assumptions about polygyny, Shoneyin's novel, in contrast, presents a polygyny that defies simple moralising and preconceptions of cultural backwardness. As far as the major characters are concerned, the secret that Baba Segi, the patriarch ostensibly at the heart of the book, is infertile, is a secret only from Bolanle, the new and fourth wife, and Baba Segi himself. (The "secret" is so well managed in the narrative that sharp readers can guess at the truth but have it finally confirmed only at the end of the novel.) The "secret" becomes apparent soon after Baba Segi's marriage to his enterprising and entrepreneurial first wife, Iya Segi, who does not conceive a child even after being taken to a medicine man by Baba Segi on the recommendation of his advisor, the unmarried shebeen owner, Teacher, who himself hides his own impotence. Iya Segi duly informs the second and third wives, Iya Tope and Iya Femi, about the secret, but she does not tell the fourth wife, Bolanle. "Iya" and "Baba" are the teknonymous terms indicating "mother of" and "father of," respectively.) Bolanle enters the Alao household with some rancour from the existing wives since she is "a graduate"-young, beautiful, and sophisticated-whom the other wives assume will steal Baba Segi's favour. The first wife, Iya Segi, goes so far as to say that, with the exception of Bolanle, she does not "blame the other women" since they are "weakened" by the prosperity Baba Segi offers (Shoneyin 104). For her the other wives are the "humble maidservants who live for a kind pat on the head from the mother-of-the-home" (104). Thus, this novel from a "third generation" Nigerian writer presents a twenty-first-century perversion of the cooperation and protective hierarchies of the polygynous household of Chinua Achebe's Things Fall Apart. While in Achebe's novel, which casts a retrospective glance at pre-colonial Nigerian society, the first wife is a genuinely motherly figure at the head of a household in which childcare, household duties, and husband management are a collective responsibility, in the twenty-first-century urban plural marriage, Shoneyin portrays the first wife as a competitive, acquisitive, and lustful "masculine" character who manipulates her husband and the other wives to her own advantage. After marriage, Iya Segi continues to develop the keen business sense she had as a young single woman, having wheedled Baba Segi into allowing her to trade in sweets. Sweet wholesaling, however, appears to be a pretext for a massive cement-selling venture, which also necessitates that Iya Segi learn to drive a car. Both the sale of building materials and driving are coded as masculine in the novel's society. In fact, reversing gender stereotypes more fundamentally, Iya Segi is the provider in the household since her significant wealth, acquired while still in the village, is secretly passed on from her mother to the mother of Ishola Alao, as Baba Segi is known before the birth of his first child. Her wealth while single was such that she, like a man, was in a position to buy land and build a house so sizeable that her objecting mother declares: "The village men will say you are ridiculing them, doing what they cant!" (97). As a closeted lesbian, Iya Segi's gaze is further coded as masculine both when she, together with the virile village carpenter, ogles a female tomato hawker and when she salivates over Bolanle's female friend who visits the household. Nevertheless, despite the jealousies and self-interested power play at work in the household, the first three wives at no point jeopardise the fundamental stability of the home, which, in a globalised Nigeria riven by the massive inequalities of the postcolonial nation state, represents the only security they enjoy. 
The novel begins with Bolanle's entry into the household and ends with her departure. Bolanle, with a formal Western education and a sophistication that the novel defines as modern, believes she can bring refinement to both the polygamist husband and the wives. When Baba Segi belches, Bolanle naively believes that she will "devote a few hours a night to teaching him good manners" (19). She also patronisingly takes on the duty of introducing the wives to the niceties of polite conversation. The novel, however, leaves considerable doubt around how one should read the character of Bolanle. The story shifts between third-person omniscient and firstperson narration and presents the histories and points of view of all of the main characters. But the story starts and ends with Bolanle entering the household, and a significant eight of twenty-eight chapters give voice to Bolanle. She appears to be the central character, the one who shows the most development and the one with whom readers are led to sympathise. Yet the wicked, rambunctious humour with which the novel is charged tempts the reader to view evens character ironically, though she is never caricatured the way the "traditional" characters are. Bolanle's determined, almost missionary commitment to uplifting the Alao household in the ironic context of her "free" choice of a "primitive" polygynous union beggars belief. Bolanle defies her authoritarian and controlling mother by eloping with Baba Segi. For Bolanle's mother, polygyny is the choice of uneducated bush-dwellers and educated gold-diggers, and Bolanle is neither of these. Polygyny presents itself to her as a refuge into which she may escape her completely dysfunctional (monogamous, modern) family and the secret of her rape and abortion. As a fifteen-year old schoolgirl, she had been duped into accepting a ride on a rainy day from a Mercedes-driving, branded polo-shirt wearing, predatory young man, part of Africa's small, new, transnational consumerist class. Playing on the idea of conception and childbirth, which is of profound literary and cultural significance in the context of the novel, Bolanle compares her violated self to a broken egg. When she finally reveals the rape to her mother in an attempt to justify her choice to enter a polygynous household, she says, "Mama, you were living with an empty shell. Everything was scraped out of me. I was inside out" (150). In this situation, the Alao household seems to provide Bolanle with the comfort she needs to become whole. Baba Segi's home is a troubled place within which to escape and to heal, but it is less troubled than the world outside.

Despite the fact that it is Bolanle who needs saving, as soon as she enters the polygynous household, she casts herself as a saviour. When she is first introduced to the family, her selfrighteous comment that she "will not give up on them" and "will bring light" to their "darkness" invites ironic interpretation (22). A further irony lies in the outcome in which Bolanle does bring light but not the Enlightenment world-view that she anticipates. Instead, she brings to light Baba Segi's infertility and the other wives' ambiguous betrayal of and loyalty toward the polygynous union when her own apparent barrenness is medically investigated.

All of the other wives engage in extra-marital affairs not as an implicit critique of the plural marriage but because of their desire for children and the preservation of the polygynous household, which for them is the only haven in a hopeless world. Children are the indisputable sine qua non of Yoruba cultural existence in the novel. Without a child one's life has no reality and one is a ghost in the world of the living. The beginning of the novel artfully highlights the significance of children by describing Bolanle's first night in the home: during their family 
television viewing time a news report about serial killings of pregnant women viscerally affects the family members and Baba Segi actually throws up. Such is the horror of foeticide. At the end of the novel, the illness and death of the eldest daughter, Segi, is cast as a cataclysmic event that challenges the natural order of parent predeceasing child. Since the birth of children ensures the survival of marriage, the wives take the initiative and stop at nothing to make sure they become pregnant. While rural polygyny allows the "open secret" of impregnation by a male relative in cases of the husband's sterility, "nuclear" polygynous families in the city have no such recourse since they live independently outside the network of extended family relations. Thus, in a surreptitious and daring take on this traditional practice, all of the wives except Bolanle are made pregnant by lovers of their choice. In what is possibly a satirical postcolonial allusion to Lady Chatterley, the apparently lesbian Iya Segi chooses the chauffeur, Taju, to impregnate her. Iya Segi may have accumulated wealth in the village like a man, and she may desire women, but she is obliged to marry and be impregnated by a man in order to have children. Her wealth allows the marriage to Ishola Alao to take place and her ingenuity allows her to be impregnated:

"My husband? Mama, women don't need husbands." I spoke her own words back to her. "You do. You need one to bear children. The world has no patience for spinsters. It spits them out."

"Is this all so I can bear children?"

"It is every woman's purpose to bear children. Do you want to become a ghost in the world of the living? That is not how I want to leave you in this world." (101)

Despite her mother's cynicism about husbands, engendered by the fact that she was callously abandoned by her own, she nevertheless recognises that with money as Iya Segi's metaphorical husband, her daughter will not fulfill the Yoruba circle of life that includes the dead, the living, and those yet to be born. Iya Segi needs to have a child to fill her place both in the narrower social and wider spiritual contexts. Once Iya Segis position is secured through childbirth, the safety of the Alao household allows her not only the urban base where her initial investment in the form of the secret dowry is safe but also the financial freedom to multiply her returns in a flourishing cement business when she theatrically, early on in the marriage, elicits her husband's sympathy and consent to allow her to trade. Her liaison with the bewildered and overwhelmed Taju is one Iya Segi entirely controls as a consequence of his poverty and her dominance in the financial and sexual arenas. Sent to the Alao home to collect a parcel, Taju is "taken," ironically since it is the symbolic seat of the patriarch's domestic power, in Baba Segi's armchair and is "ridden like a new saddle" by the wife, Iya Segi, whenever her need to conceive arises (223).

In contrast to the dominating, shrewd first wife, the second wife, Iya Tope, is the daughter of an indigent farmer given to Baba Segi to repay a debt. She is childlike, unattractive, simple-minded, and clearly unable to fend for herself either in the countryside or the city. She is quickly inducted into the household's "secret" by Iya Segi, but quite unexpectedly, unlike the more practical-minded first wife, takes a far more pleasurable view of the task of conceiving a child. Iya Tope takes up with a "meat-seller" who sells his flesh both literally and figuratively. Iya Tope, by far exceeding the 
"brief" given by Iya Segi to get herself impregnated, visits the meat-seller weekly for the carnal delights he offers, and each subsequent visit repeats the pleasures of the first:

He led me to his home and he took me. I will never forget that day or any other that I spent with him. He made my body sing. He made me howl when he bent me over; he made me whimper when he sat me on his belly. And when he took me standing up, it was as if there was a frog inside me, puffing out its throat, blowing, blowing and blowing until whoosh-all the warm air escaped through my limbs. (85)

Reversing the conventional urban African paradigm of the "sugar daddy" who enjoys de facto polygyny in an "outside marriage," the naïve, unsophisticated Iya Tope becomes a "sugar mommy" with her own polyandrous "outside marriage." Her amatory relationship ends only when Iya Segi admonishes her for taking risks that threaten the household: "I will not let you threaten this home with your excess. You have allowed the concubine to become the husband. I have not known anyone to enjoy the penis the way you do!" (86). Iya Tope is also overcome with remorse since her sex addiction leads her to neglect her children who have "bought [her] the easy life [she] lived" (87). Neither Iya Segi, the only character aware of these carnal trysts, nor the third person narrator in the novel appear morally affronted by Iya Tope's sex addiction. It is simply a facet of her personality, like her stunted intellect. Iya Segi condemns it as a problem only when Iya Tope's absent-mindedness and neglect to cover her trail threaten to expose her adultery and thus jeopardise the stability of the polygynous household, which is Iya Segi's main concern.

The third wife, Iya Femi, proposes marriage to Baba Segi in an effort to escape her life of abjection as a house-girl in a wealthy family. After the death of her parents, she had been sold by her uncle into domestic slavery, presided over by an especially tyrannical and cruel matriarch referred to simply as "Grandma." Iya Femi is a kind of Pamela figure: she gives in to the belowstairs overtures of the "hedonist" son, Tunde (136), who, perversely, believes that his physical relationship with the maid is an expression of his anti-establishment views and an embodiment of her potential liberation. Unlike Pamela, social barriers prevent Iya Femi from entering the class of the new African elite through proving her bourgeois morality, since the rules of bourgeois morality do not prevail in this context. Iya Femi marries Baba Segi to escape her daily humiliations but continues to enjoy the erotic pleasures of her liaison with Tunde in the mistaken belief that their relationship is cemented by mutual sexual attraction. Iya Femi dreams of double revenge, in which the Alao household is the launchpad. Her first act of vengeance is successful. She returns to her village, where she burns the home stolen from her by her uncle. Her second dream of revenge is to triumphantly return to the house in which she worked, with Tunde's children (brought up as Baba Segi's) in tow, for her final victory over Grandma. This ambition is foiled, however, when she discovers from a general photocopied farewell note Tunde left at his office that he has unceremoniously abandoned her for a job as a "US rep" after his mother's death. In it he requests that acquaintances get in touch by email: "I ask you: what is email? And what is a US rep? Ha! God! Is this your face? I could not stop the tears of anger that wet my face. I cried. So there is no Grandma to parade my sons in front of? Ha! Coward! She saw my triumph coming and decided to deny my victory!" (167). Iya Femi is de facto polyandrous, then, in her 
long-standing extra-marital relationship, which reverses the well-known French convention of the long-time mistress.

Thus a novel which purportedly shows the oppression of voiceless women under the patriarchal system of traditional polygyny portrays one wife who is the Nigerian equivalent of the Victorian self-made man, who dreams of one day indulging her lesbian inclinations and eyes young women from the top of her multi-storey mansion. It presents a second wife who is a simple-minded but well-intentioned sex addict and a third wife who, unlike Lady Macbeth, acts on her vaulting ambition herself and not by proxy. In the contemporary Nigerian context in which they find themselves, these avenues open up from the space of the polygynous household, which is secured only through procreation. Bearing children, rather than romantic love, has been the foundation of African cultural approaches to marriage. (The corollary of this idea is not, however, that love does not exist, but rather that love is not the major social rationale for marriage.) Paradoxically, the wives of this formal polygynous household become informally polyandrous in order to protect the material and emotional well-being it represents despite the occasional prickles of urban polygyny. They also make the rational choice to stay in the household even when they have the opportunity to leave at the end of the novel. Their decision is not motivated by, nor does it aspire to, any Yoruba cultural ideal or notion of Yoruba identity. Moreover, Secret Lives presents the rural model of the polygynous household transposed into the city. In doing so, it does not represent the urban monogamised polygyny described in Aidoo's Changes. Shoneyin's novel complicates the modern trend Changes depicts, in which men appeal to tradition to formalise adulterous relationships with women who are then married and kept in separate homes. This model jettisons the ritual, hierarchies, sororities, and sharing of responsibilities attendant upon the rural "compound" version of polygyny. In Secret Lives, urban polygyny shares the relationship and domestic architecture of the rural polygyny of Achebe's "pre-colonial" novels but meets personal and cultural needs in a postcolonial, modernised, globalised Nigeria.

Shoneyin's novel, in its Rabelaisian exuberance, sends up most of the author's assumptions on the question of polygyny and underlines a disconnect between an "informal" theory and practice of writing. Shoneyin's Guardian article implies that polygyny is a traditional institution with no place in the modern world; that it inherently oppresses women; that household rivalries, jealousies, and hierarchies are completely destructive of wives and children; and that polygyny obstructs the progress and development narrative of the political elites of the developing world. Yet Shoneyin's novel, astonishingly, destabilises every one of these postulates, confirming Stacey's observations that, "paradoxically, the very globalizing market and media forces that disperse Western individualism, gender and sexual identity politics, and modern transformations of intimacy around the planet also exacerbate the conditions . . . that inspire many forms of plural marriage" (144). Although Stacey's study does not specifically focus on Nigeria, it does consider the parallel example of South Africa. Significant differences exist between the two countries-in particular, the South African experience of apartheid. But the macro- and micro-structural transformations forced by colonialism, and the post-independence inheritance of political institutions which may not have local cultural purchase leading to corruption and mismanagement, are similar in both countries. These historical legacies have 
been further exacerbated by the terms on which African economies are integrated into latecapitalist global economic networks. While Secret Lives at no point shifts its gaze from the minutiae of personal relations to larger historical, economic, political, and epistemological forces, it describes a very familiar twenty-first-century African world in which global economics and culture enforce local shifts and, to use Arjun Appadurai's terms, "mediascapes" that project affluent Western lifestyles unsupported by African "finanscapes" (101). The Ibadan described by the novel is the well-known African city that projects consumerism and affluent lifestyles as ethical horizons that material conditions make it impossible for most people to achieve. Apart from the peripheral upper-middle-class characters like the man who rapes Bolanle and the family of Segun, Bolanle's first true love, Iya Segi is the only character who prospers financially. All of the other characters endure lives of inescapable poverty that drive them to act in morally and culturally reprehensible ways in order to survive. In fact, the dominant tone of the novel is of poverty and hardship, foreshadowed by the lyrics of the signature song of a television soap opera: "The impoverished search for cassava flour / While the rich consume rice by the measuring bowl" (Shoneyin 9). In this world, the market and media forces that promote monogamous romantic love also create the conditions in which polygyny is the only option for both uneducated and formally educated women, as Stacey also shows in her sociological study of contemporary South Africa. Stacey's conclusion is reinforced by the studies in David Parkin and David Nyamwaya's edited volume, Transformations of African Marriage. These essays suggest that polygyny is attractive not only to men but also to some women for whom it proffers more freedom than is otherwise available. Clearly, considering the backgrounds of and social possibilities for the first three wives in Shoneyin's novel, the polygynous household in the cultural and economic context of contemporary urban Nigeria, while not exactly utopian, offers some women far greater potential for expressing their material, personal, sexual, maternal, emotional, and social desires than marriages or partnerships that conform to the hegemonic norms of acceptable monogamous intimate relationships.

Secret Lives also tests the judgments of its author in other ways. In the first place, it destabilises the familiar dichotomy that underpins analyses of intimate relations in which polygyny is associated with the timeless and unchanging village and monogamy with the transforming modernity of the city. Two of the wives, Iya Tope and Iya Femi, come from monogamous Yoruba and Muslim families in the village, where religious sanction of polygyny is supposed to reinforce indigenous African customs but in this case does not. Iya Segi and the husband, Ishola Alao, come from single parent families headed by strong and successful village matriarchs. Traditional family relationships thus appear quite unproblematically to encompass monogamy and single parent families whose households sometimes suffer extreme poverty but seem generally settled, happy, and secure. In fact, Iya Femi's parents appear to be very much in love and inseparable even in their deaths, which occur when "a log slip[s] from a lorry and crush[es] them on a road they travelled every day" (Shoneyin 121). By contrast, modern city monogamies are fraught relationships that are sometimes de facto polygynous. Bolanle's parents are in a monogamous union where "for life" means not till they are parted by death, as is the case with Iya Femi's "traditional" parents, but rather that the family is a prison for the emasculated (as opposed to sterile or impotent) father who escapes through drink and a prison for the two daughters who escape through doomed relationships. The other 
marriage encountered in the city is that of the parents of Segun, Bolanle's first true love. Segun's father is the wealthy landlord of the large middle-class housing estate on which Bolanle's parents are tenants. Segun's father is a public philanderer whose informal polygyny his wife tacitly accepts for the sake of her material well-being and social position. On one of her secret visits to Segun's suite in the family's lavish mansion-the same night the family is attacked by a gang of armed robbers-Segun confides his embarrassment of his nightclubbing father to Bolanle: "I could have been sitting there having a drink with $m y$ friends and we would all have seen my father walk in with a girl on each arm" (181; emphasis in original).

The novel also makes, through Bolanle, a somewhat contradictory case for romantic love as the sole foundation of the modern monogamous marriage that the author endorses. Bolanle, like an Austen heroine, is an avid reader of romance fiction, a genre which is growing apace in Africa with dedicated African romance imprints like the Nigerian Ankara Press and even bigger digital growth with romance fiction published online, for example the Valentine's Day Story Anthology available for download as a PDF document. Ironically, Bolanle pretends to go to bed early to read her Mills and Boons as a pretext to escape to her boyfriend's home on the night Segun's family is robbed and his father is killed. Bolanle's teenage love affair has all of the hallmarks of the classic romance fiction scenario, namely a young, attractive, intelligent heroine of aspirant social class and a desirable, wealthy, somewhat unattainable hero. Bolanle's dreams of romance, however, are shattered when Segun, subject to the terrors and humiliations of the armed robbery, which the pair watch hidden in the en-suite bathroom roof, does not acknowledge Bolanle at all:

I reached out my hand to him but he pretended not to see it. He wished I wasn't there. Not to save me from the terrible things I was seeing but because he was embarrassed that I, a common tenant, was witnessing such a personal family tragedy. It was at that moment that I realised that I meant very little to him. I might have been another dusty lintel. I thought perhaps I wasn't worthy of him. (184)

The relationship is finally brought to a close when Segun turns away from her as his father's funeral cortège passes. When Bolanle visits her parents' home after her marriage to Baba Segi, a marriage that is roundly condemned by her aspirant mother in particular, Bolanle comes across her old Mills and Boons. As if to put paid to the idea of romance in the riven world in which she finds herself, Bolanle discovers that her rebellious sister, Lara, has drawn sardonic moustaches on all of the heroines. Later, when she is married to Baba Segi, Bolanle burns the copy of The Long Honeymoon that she comes across among her mementos, finally jettisoning dreams of love as figured by popular romance novels, but not the concept of monogamy as a marriage ideal.

Even though, in interviews, Shoneyin may paint a picture of the polygynous patriarch as a smug, self-interested hypocrite, Baba Segi is much more complex and open-ended. Yes, he is presented as grotesque and obnoxious with gross naturalistic flourishes, but he is a devoted, loyal husband and father, unlike the modern, educated, libertarian Tunde, who uses Iya Femi and then abandons her to follow his career in the US, or Segun, who similarly uses Bolanle. Indeed, Iya Femi, underlining the emotional and material securities of the home, 
perhaps expresses the sentiment of the other wives most forcefully when she says, "Not even God Himself could have made me leave Baba Segi's house" (130).

\section{Closure: The Costs and Promises of Enlightenment}

The final chapter of the novel is titled "Bolanle" since at this point in the narrative the central character achieves self-realisation. While earlier in the novel Bolanle is a broken egg, in the end she is whole, and the difficult world full of privation and challenge is "like an egg cracked open" (245). Yet one might read the image of the cracked egg as representing the possibilities that lie before her in the world-possibilities which demand the breaking of the shell. In this case, the broken shell is the troubled equilibrium of the Alao household.

Bolanle's arrival and the light of medical knowledge she brings into this dark household comes at the price of the death of the eldest daughter, Segi, whom her mother kills by accident: she intended to poison Bolanle's food to prevent the exposure of the family's secret. Baba Segi, or the "father of Segi," loses his status as father with the death of the daughter. With the revelation of his infertility, he also loses the status of father of all the other children. Throughout the novel, Baba Segi is a benevolent albeit crude and uncultured patriarch who, in fact, is soft-hearted and whose wives have free reign provided they meet his physical needs. Following the exposure of his infertility, Baba Segi gives his wives and their children the opportunity to leave. With the exception of Bolanle, who opts to return to her parent's house, they all stay, recognising that they would be lost in the merciless world outside of the household. In the light of the contradictory modernity Bolanle brings, that in this case exposes Baba Segi's humiliating secret, the patriarch enforces a seclusion on the wives-which is not part of African polygyny and male-female relations-and strips them of the freedoms and indulgences they had hitherto enjoyed:

An agreement was drawn up: they could stay if they promised to be the wives he wanted them to be. He promptly banned them from leaving the house without his permission. Iya Segi was instructed to close down all her shops and relinquish every kobo she had saved to him. Iya Femi was forbidden to wear make-up and there would be no more church. God hears your heart no matter where you are, he'd said. (243)

While the revelation of the secret results in the foreclosure of the lives of the other wives, it precipitates Bolanle's epiphany that allows her to become emotionally whole. Baba Segi turns to her with renewed care and respect since she is the only wife that has not betrayed him. Although she tells him that continuing the marriage would be meaningless since there is no hope of children, she regards the household and her sojourn in it as a dark night which paradoxically "shook [her] awake" (244). Her time in the house is a "dream of unspeakable selfflagellation" (244). She realizes, furthermore, that she was "in the midst of strangers, people from a different time in history, a different world" (244), which reinforces the tradition-modernity divide partly endorsed by the novel. The novel ultimately presents the polygynous household as a prison in which the wives are the "inmates" who are "going nowhere," while Bolanle "rejoins [her] life's path" (245). 
The novel's ending thus reinforces the conventional assumptions and stereotypes of the oppression and stasis of the "traditional" institution of polygyny, while the dynamic energy of the body of the narrative portrays polygyny as the deliberate and intelligent response of women whom the globalised postcolony leaves with few other choices. Bolanle, in contrast, firm in her conviction of the civilisational superiority and progressiveness of monogamy, rejoins her life's path that, by implication, will ultimately lead her to future fulfillment in an exclusive, idealised life relationship. 


\section{Works Cited}

Achebe, Chinua. Things Fall Apart. London: Heinemann, 1958. Print.

Aidoo, Ama Ata. Changes: A Love Story. London: Women's, 1991. Print.

Aluko, T. M. One Man, One Wife. 1959. London: Heinemann, 1967. Print.

Appadurai, Arjun. "Disjuncture and Difference in the Global Cultural Economy." Readings in Contemporary Political Sociology. Ed. Kate Nash. Malden: Blackwell, 2000. 100-14. Print.

Bâ, Mariama. Trans. Modupé Bodé-Thomas. 1980. So Long a Letter. Oxford: Heinemann, 1989. Print.

Barash, David P., and Judith Eve Lipton. Strange Bedfellows: The Surprising Connection Between Sex, Evolution and Monogamy. New York: Bellevue, 2009. Print.

Cole, Jennifer and Lynn M. Thomas, eds. Love in Africa. Chicago: U of Chicago P, 2009. Print. Danquah, Mabel Dove. "Anticipation." Unwinding Threads: Writing by Women in Africa. Ed. Charlotte H. Bruner. London: Heinemann, 1983. 3-7. Print.

Emecheta, Buchi. "Feminism with a small 'f '!" Criticism and Ideology. Ed. Kirsten Holst Petersen. Stockholm: Scandinavian Institute of African Studies, 1988. 173-85. Print.

—. The Joys of Motherhood. 1979. Oxford: Heinemann, 1988. Print.

Gikandi, Simon. Encyclopaedia of African Literature. Routledge: London, 2003. Print.

Gikandi, Simon and Evan Mwangi. The Columbia Guide to East African Literature in English since 1945. New York: Columbia UP, 2007. Print.

Karlekar, Malavika. "Reflections on Kulin Polygamy: Nistarini Debi's Sekeley Katha." Social Reform, Sexuality and the State. Ed. Patricia Uberoi. New Delhi: Sage, 1996. 135-55. Print.

Maillu, David. Our Kind of Polygamy. Nairobi: Heinemann, 1988. Print. Murdock, George Peter. Ethnographic Atlas. Pittsburgh: U of Pittsburgh P, 1967. Print.

Nnaemeka, Obioma. "Urban Spaces, Women's Places: Polygamy as Sign in Mariama Bầs Novels." The Politics of (M)othering: Womanhood, Identity and Resistance in African Literature. Ed. Obioma Nnaemeka. Routledge: London, 1997. 163-92. Print.

Nwoye, Augustine. "The Practice of Interventive Polygamy in Two Regions of Africa: Background, Theory and Techniques.” Dialectical Anthropology 31 (2007): 383-421. SpringerLink. Web. 28 May 2015.

Okpewho, Isidore. The Victims. Harlow: Longman, 1970. Print.

Parkin, David, and David Nyamwaya, eds. Transformations of African Marriage. Manchester: Manchester UP, 1987. Print.

Parrinder, Geoffrey. Sexual Morality in the World's Religions. Oxford: Oneworld, 1980. Print.

Shoneyin, Lola. "Polygamy? No Thanks." Theguardian.com. Guardian News, 20 Mar. 2010. Web. 27 May 2015.

--. The Secret Lives of Baba Segi's Wives. London: Serpent's Tail, 2010. Print.

Sithole, Ndabaningi. The Polygamist. London: Hodder, 1973. Print.

Spivak, Gayatri Chakravorty. "Can the Subaltern Speak?" Colonial Discourse and Post-Colonial Theory: A Reader. Ed. Patrick Williams and Laura Chrisman. New York: Columbia UP, 1994. 66-111. Print.

Stacey, Judith. Unhitched: Love, Marriage and Family Values from West Hollywood to Western China. New York: New York UP, 2011. Print. 
Stone, Lawrence. The Family, Sex and Marriage in England 1500-180o. London: Weidenfeld, 1977. Print.

Valentine's Day Anthology 2015. Nigeria: Ankara, 2015. Ankarapress.com. Web. 12 Nov. 2016. Zeitsen, Miriam Koktvedgaard. Polygamy: A Cross-Cultural Analysis. Oxford: Berg, 2008. Print. 